\title{
A Systematic Review of Telehealth Applications in Audiology
}

\author{
De Wet Swanepoel, Ph.D., ${ }^{1,2}$ and James W. Hall, III, Ph.D. ${ }^{3,1}$ \\ ${ }^{1}$ Department of Communication Pathology, University of Pretoria, \\ Pretoria, South Africa. \\ ${ }^{2}$ Callier Center for Communication Disorders, School for \\ Behavioral and Brain Sciences, University of Texas at \\ Dallas, Texas. \\ ${ }^{3}$ Department of Communicative Disorders, University of Florida, \\ Gainesville, Florida.
}

\section{Abstract}

Hearing loss is a pervasive global healthcare concern with an estimated $10 \%$ of the global population affected to a mild or greater degree. In the absence of appropriate diagnosis and intervention it can become a lifelong disability with serious consequences on the quality of life and societal integration and participation of the affected persons. Unfortunately, there is a major dearth of hearing healthcare services globally, which highlights the possible role of telehealth in penetrating the underserved communities. This study systematically reviews peer-reviewed publications on audiologyrelated telehealth services and patient/clinician perceptions regarding their use. Several databases were sourced (Medline, SCOPUS, and CHINAL) using different search strategies for optimal coverage. Though the number of studies in this field are limited available reports span audiological services such as screening, diagnosis, and intervention. Several screening applications for populations consisting of infants, children, and adults have demonstrated the feasibility and reliability of telehealth using both synchronous and asynchronous models. The diagnostic procedures reported, including audiometry, video-otoscopy, oto-acoustic emissions, and auditory brainstem response, confirm clinically equivalent results for remote telehealth-enabled tests and conventional face-to-face versions. Intervention studies, including hearing aid verification, counseling, and Internet-based treatment for tinnitus, demonstrate reliability and effectiveness of telehealth applications compared to conventional methods. The limited information on patient perceptions reveal mixed findings and require more specific investigations, especially post facto surveys of patient experiences. Tele-audiology holds significant promise in extending services to the underserved communities but require considerable empirical research to inform future implementation.

\section{Introduction}

he field of audiology encompasses prevention, assessment, and rehabilitation of hearing, auditory function, balance, and other related systems. ${ }^{1,2}$ With an estimated 642 million people in the world affected to a mild or greater degree, and 278 million to a moderate and greater degree, hearing loss is clearly a significant global healthcare concern ${ }^{3}$ with pervasive and farreaching consequences. If not identified and treated early, children with hearing loss may suffer lifelong disability due to developmental delays in language, literacy, academic achievement, and social wellbeing. ${ }^{4,5}$ Hearing loss in adults tends to isolate and stigmatize them, leading to poor social participation and severely restricting vocational opportunities, as evidenced by significantly higher under- and unemployment. ${ }^{6}$ Hearing loss is therefore reported as one of the most significant contributors to the global burden of disease. ${ }^{7}$

Audiological diagnosis and intervention for children and adults with hearing loss offer the possibility of excellent outcomes as opposed to the negative consequences of undetected and undiagnosed hearing loss without intervention services. ${ }^{8,9}$ The problem in providing the necessary services, however, is the shortage of audiological professionals and services in the majority of regions in the world. ${ }^{10,11}$ Even in developed countries like the United States and Australia, rural and remote communities may not be able to access the necessary hearing healthcare services. Telehealth applications in audiology may offer some solutions to the mismatch in the apparent need for services and the limited capacity to deliver services. ${ }^{12}$ Using information and communication technology in healthcare, as implied in telehealth, 
holds significant promise in improving healthcare access, quality of service delivery, and the effectiveness and efficiency of services. Employing different models of telehealth service delivery in audiological practice, such as synchronous (real-time), asynchronous (store-and-forward), and hybrid models, may improve the reach of audiological services to underserved communities globally. ${ }^{13}$

Professional bodies in audiology have proposed tele-audiology as a valid means of delivering services, but more studies are necessary to ensure these services are comparable to face-to-face service provision. ${ }^{14,15}$ The aim of this study was to review the current body of peer-reviewed publications on available empirical studies of audiology-related telehealth services and patient/clinician perceptions regarding its use.

\section{Materials and Methods}

To perform a systematic review of tele-audiology, a search was conducted for articles in peer-reviewed journals reporting empirical investigations related to audiological services with a telehealth component or patient/clinician perceptions of telehealth for audiological services. There was overlap between audiological and otological practices in the area of otoscopic examinations. Any report within the scope of the review, whether related to otology or audiology, was therefore considered for inclusion. The exceptions included cases where a microscope/endoscope was used at the remote site, because audiologists typically do not use these devices; studies specifically related to medical diagnoses of ear disease; and reports providing comparison between devices. All relevant reports published until May 31, 2009, were included.
A varied search strategy was employed to extract relevant peerreviewed reports in English from several databases as illustrated in Appendix I. The Medline database was searched using three distinct strategies: (1) using MeSH terms to search for reports related to audiology and telemedicine, (2) searching for audiology-related reports in telemedicine journals, (3) searching for telemedicine-related reports in audiology-related journals. The SCOPUS database, which also covers Medline, was searched using a combination of terms related to audiology and telemedicine occurring in the same report. The third database searched was CINAHL, for which main subject words relating to audiology and telemedicine were used as identifiers. This multipronged approach covering multiple databases with variations in search strategy was employed to maximize the coverage and to cross-check results. Reference lists in the reports finally selected for review were subsequently surveyed to identify any additional report applying to the scope of the study that was not obtained through the database searches.

The reports selected for review were carefully studied and subsequently categorized according to four criteria specifying their scope of relevance: (1) audiological screening, (2) audiological diagnosis, (3) audiological intervention, and (4) patient/clinician perceptions.

\section{Results}

Table 1 describes the search results according to the procedural steps applied. We reviewed the abstracts of 261 reports to determine if they were in any way relevant to the scope of the study. Sixty-three reports indicated some relevance and these were subsequently reviewed. A total of 25 articles were identified to be directly within the

\section{Table 1. Description of Search Results Identifying Reports for Inclusion \\ PROCEDURAL STEPS \\ NUMBER OF REPORTS}

(a) Database search results

(b) Database search results-duplicates omitted

(c) Database reports related to scope of review

(d) Database reports within scope of review

(e) Additional reports within scope of review

(f) Final reports for review
386

261

63

25

\section{DESCRIPTION}

3 databases (Medline, SCOPUS, and CINAHL); 5 search strategies

125 duplicates from the 5 searches were omitted

261 abstracts reviewed for relevance; 198 reports omitted.

39 reports were not directly relevant to scope of review.

Reports included from survey of reference lists; only those reports not contained in database search

Articles constituting the systematic review 


\section{TELEHEALTH APPLICATIONS IN AUDIOLOGY}

scope of the systematic review. A survey of the reference lists in these articles revealed a single additional report not identified by the database searches, which brought the number of reports for final review to 26. These reports, which date from 1997 to 2009, are briefly summarized in Appendix II according to authors and year of publication, journal, category, study type, connection/model, subjects, procedures, and conclusions.

The reports were divided into four categories as illustrated in Table 2. The majority of reports were concerned with diagnosis, while two exclusively considered patient perceptions related to teleaudiology. Three of the reports on intervention also included a section on patient perceptions. A variety of audiological procedures or techniques were used across the categories of screening, diagnosis, and intervention in a combination of synchronous, asynchronous, and hybrid models.

\section{Discussion}

\section{AUDIOLOGICAL SCREENING}

Five reports on audiological screening using telehealth configurations were identified. Screening procedures included pure tone audiometry, tympanometry, oto-acoustic emissions (OAE), and automated auditory brainstem response (AABR) used in populations varying from infants to adults. Three reports described self-test screening procedures; two of these used speech-in-noise screening and one described pure tone audiometric screening. ${ }^{16-18}$ Smits and colleagues ${ }^{16}$ reported on the development and validation of a speechin-noise screening procedure using triple digits and an adaptive procedure that can be used reliably over the telephone and computer headsets. They subsequently reported on a national self-screening program in the Netherlands using this test to screen large numbers of adolescents and adults using the telephone $(n=6,351)$ or Internet $(n=30,260) .{ }^{17}$ The participation in this program was high, but the elderly population used the telephone-based test in preference to Internet-based screening. The compliance of the Internet-based test was compromised because few people (31\%) used headphones, which are necessary for a more reliable and valid screening.

A self-test, Internet-based, pure tone audiometry screening procedure was reported by Bexelius and colleagues. ${ }^{18}$ This proof-ofconcept study screened patients by determining threshold frequencies between 500 and $8,000 \mathrm{~Hz}$ as against a more conventional screening criterion that assesses hearing at a preset intensity across a limited range of frequencies. This study tested the members of a hunting organization and reported poor participation in the self-test, but demonstrated that Internet-based hearing screening tests can be performed. Self-test, Internet-based screening is, however, confounded by the lack of control over environmental variables at the remote test site, such as noise levels and transducer type, which makes these procedures no better than a preliminary screening. Validated procedures such as the triplet speech-in-noise test used in the Netherlands may be more useful. All these procedures may ultimately

\begin{tabular}{|c|c|c|c|c|}
\hline CATEGORIES & NO. OF REPORTS & STUDY POPULATIONS & PROCEDURES/TECHNIQUES & TELEHEALTH MODELS \\
\hline Screening & 5 & Infants, children, and adults & $\begin{array}{l}\text { Video-otoscopy, immittance, OAE, AABR, } \\
\text { audiometry, speech-in-noise }\end{array}$ & $\begin{array}{l}\text { Synchronous, asynchronous, } \\
\text { hybrid, and self-test }\end{array}$ \\
\hline Diagnosis & 12 & Children and adults & $\begin{array}{l}\text { Video-otoscopy, audiometry } \\
\text { (AC and } B C), H I N T, A B R \text {, } \\
\text { intraoperative monitoring, balance } \\
\text { testing }\end{array}$ & $\begin{array}{l}\text { Synchronous and } \\
\text { asynchronous }\end{array}$ \\
\hline Intervention & 7 & Adults & $\begin{array}{l}\text { HA fitting and verification, } \mathrm{Cl} \\
\text { programming, tinnitus therapy, } \\
\text { HA counseling }\end{array}$ & $\begin{array}{l}\text { Synchronous and } \\
\text { asynchronous }\end{array}$ \\
\hline Patient perceptions & $2\left(3^{a}\right)$ & $\begin{array}{l}\text { Adult clinic patients, tinnitus } \\
\text { patients, cochlear implant } \\
\text { mapping patients }\end{array}$ & Questionnaires & $\begin{array}{l}\text { Synchronous and } \\
\text { asynchronous }\end{array}$ \\
\hline
\end{tabular}

${ }^{a}$ Reports of audiological intervention also including patient perceptions.

AABR, automated auditory brainstem response; ABR, auditory brainstem response; $A C$, air conduction; $B C$, bone conduction; $C$, cochlear implant; $H A$, hearing aid; HINT, Hearing-in-Noise-Test; OAE, oto-acoustic emissions. 
improve public awareness regarding the risks of hearing loss and the importance of hearing healthcare.

The other two reports on audiological screening compared faceto-face screening with remote screening of infants using AABR and $\mathrm{OAE}^{19}$ and of young children using otoscopy, pure tone audiometry, and tympanometry. ${ }^{20}$ A synchronous setup using videoconferencing and application sharing was used to screen infants remotely. The onsite audiologist prepared the tests and conducted two face-to-face assessments, while the remote audiologist conducted one test. The tests were randomized and testers were blind to the results. Telehealth screening provided exactly the same results as face-to-face screening, and comparison of distortion product OAE (DPOAE) amplitudes showed these were equivalent within typical test-retest reliability limits. The second report compared telehealth hearing screening with on-site screening of 32 children in a rural elementary school. Otoscopic examination and pure tone testing were conducted synchronously, while tympanometry was interpreted asynchronously in a store-and-forward model. The testing was counterbalanced to avoid an order effect, and examiners were blinded to each other's results. The interpretation of otoscopy and tympanometry were identical, and screening responses on pure tone audiometry were perfectly correlated in 188 of 193 frequencies tested. These differences translated to four false-positive and one false-negative screen results using telehealth. However, in the context of the large number of frequencies tested, this did not constitute a statistically significant difference. The authors note that although similarly high test sensitivity values were obtained for face-to-face and remote screening, the test specificity for pure tone audiometric screening may be slightly less for a telehealth setup.

\section{AUDIOLOGICAL DIAGNOSIS}

Four of the 12 reports on audiological diagnosis investigated hearing evaluations using pure tone audiometry in a sound booth or sound-treated room from remote locations. ${ }^{21-24}$ All studies were performed on adult subjects using air conduction audiometry (250$8,000 \mathrm{~Hz}$; octave frequencies), and one also used bone conduction audiometry (250-4,000 Hz; octave frequencies). Two of the four studies reported on the same data set. One of these was a preliminary report, and therefore only the second report was considered. ${ }^{21,22}$ This study by Givens and Elangovan ${ }^{22}$ compared air $(n=45)$ and bone conduction ( $n=25$ ) pure tone thresholds determined using conventional face-to-face audiometry with thresholds determined through remote synchronous audiometry. The remote audiologist controlled the conventional audiometer through a control unit, which was accessed through the Internet from a remote personal computer (PC) or handheld device (unspecified distance and bandwidth). Audiologists were blind to results from the remote or face-to-face settings, and the testing order was counterbalanced. Mean differences between thresholds obtained with the two methods varied by no more than $1.3 \mathrm{~dB}$ for air and 1.2 $\mathrm{dB}$ for bone conduction, and Pearson correlation coefficients across frequencies varied between 0.82 and 0.97 . Statistically there was no significant difference between test results from the remote versus face-to-face methods. ${ }^{22}$

In a similar experimental setup, Choi and colleagues ${ }^{23}$ compared face-to-face audiometry using a PC-based audiometer with remote testing ( $1 \mathrm{~km}$ distance) over the Internet (broadband, unspecified bandwidth) on 12 adult subjects with normal hearing capabilities. Threshold comparisons revealed a difference of more than $5 \mathrm{~dB}$ in only $10.7 \%$ of cases $(18 / 168)$ and none differed by more than $15 \mathrm{~dB}$. Comparisons for this same sample between face-to-face audiometry on the PC-based system and on a conventional audiometer revealed a smaller percentage (3.7\%) of differences exceeding $5 \mathrm{~dB}$. The fourth study also used a PC-based audiometer remotely controlled via application sharing software with interactive videoconferencing for communication to test 30 adult subjects. ${ }^{24}$ Audiologists were blind to results in the face-to-face and remote test methods. The order of tests were rotated to avoid an order effect, and remote testing was conducted from a distance of $1,100 \mathrm{~km}$. No statistically significant difference was noted between the two methods, and the thresholds corresponded within $5 \mathrm{~dB}$ of each other in $97 \%$ of cases. A comparison of face-to-face threshold values yielded $99 \%$ correspondence. ${ }^{24}$

The only speech audiometric procedure reported with relevance to telehealth has been the Hearing-in-Noise-Test (HINT). A comparison of face-to-face evaluations to remote testing through the same local area network and a different, more remote Internet connection was reported for a group of 20 adults. ${ }^{25}$ The means and standard deviation for each test condition from both test sites were within the normative data reported for HINT, except for one instance where the difference in means between tests sites was less than $1 \mathrm{~dB}$, indicating the reliability of performing HINT via a telemedicine configuration.

Three studies of video-otoscopy facilitated through telemedicine applications were included in the review, even though all examinations were conducted by physicians as opposed to audiologists. ${ }^{26-28}$ The first study compared the interpretation of face-to-face microscopic examinations of the ear canal and tympanic membrane to video-otoscopic still images of 40 subjects, including adults and children. ${ }^{26}$ The still images were reviewed at 6 and 12 weeks post face-to-face examination, and findings were compared between the test conditions and between two independent examiners. Observations on video-otoscopic still images and microscopy were compa- 


\section{TELEHEALTH APPLICATIONS IN AUDIOLOGY}

rable (88\% concordance), which corresponded to the concordance between independent face-to-face examinations (84\%). A follow-up study found the concordance between video-otoscopic images of the tympanic membrane taken in remote clinics and in-person microscopic examinations for follow-up care in children aged 1-16 years (70 ears) following tympanostomy tube placement. ${ }^{27}$ Two otolaryngologists conducted the face-to-face examinations and also examined the images at 8 and 14 weeks postexamination. Image quality was rated adequate or better in 79\% of cases, and the majority of poor-quality images (50\%) were of 2-year-olds, who accounted for $26 \%$ of the total number of cases. Analyses revealed a high level of concordance between face-to-face microscopic examinations and corresponding image reviews. The authors concluded that videootoscopy image reviews of the tympanic membrane are comparable to an in-person examination for assessment and treatment in followup care for tympanostomy tubes. ${ }^{27}$ A similar study on 66 children (127 ears) compared face-to-face otoscopy to digital images interpreted 1 month later, which revealed significant agreement $(p<0.05)$ between clinically important observations. The agreement between otological recommendations from images and face-to-face examinations was also statistically significant ( $p<0.01$ ), although the rates of referrals were $4-16 \%$ higher. ${ }^{28}$ A significant correlation was also reported between image quality and age of the subject, with better quality images generally reported for older children.

Reports of tele-audiology using objective measures of auditory functioning have included DPOAE, ABR, and intraoperative monitoring. ${ }^{24,29,30}$ A study investigating the correspondence between DPOAE measures recorded remotely (through desktop sharing software and interactive video) and face-to-face assessments in 30 adult subjects demonstrated that there were essentially no differences between the findings. ${ }^{24}$ An overall agreement of 97-99\% was reported across frequencies $(2,000,2,500,3,000,4,000$, and 5,100 Hz) and was comparable to the agreement between face-to-face assessments, which was $97 \%$ on average. In a comparison between remote $A B R$ recordings using desktop sharing software and face-to-face recordings in a group of 15 adults, comparable wave latencies within the clinically allowable range of variability were obtained. ${ }^{29}$ Recordings included ABRs elicited with toneburst (500 and 3,000 Hz) and broadband click stimuli presented at 55 and $75 \mathrm{~dB}$. No significant effect as a result of different test sites was reported, and the results suggested that remote test was as reliable as face-to-face testing. Remote intraoperative evaluation of the cochlear implant device and responses to electrical stimulation was recently reported as a time-saving, practical, and cost-efficient option. ${ }^{30}$ Desktop sharing software was used to conduct and time four sequential remote monitoring sessions followed by four sequential on-site monitoring sessions. Remote testing was easily performed and lasted 9 min on average compared to $93 \mathrm{~min}$ required for on-site testing.

Other reports include a remote consultation for a balance disorder and the use of online forms for tinnitus evaluations. Only one report was sourced in regard to balance assessment through telemedicine. ${ }^{31}$ This single case study demonstrated the feasibility and success of a remote consultation using a two-way digital video and audio network for assessing a patient with benign positional vertigo. The use of cameras allowed for viewing the patient's eye movements, which were essential to the diagnosis. A report on the use of an online evaluation form for anxiety and depression related to tinnitus was included as part of a diagnostic tinnitus assessment to measure the self-perceived effect of tinnitus on life activities and functioning. ${ }^{32}$ Online forms completed by 157 adult patients were compared to questionnaires completed on paper and with pencil by other patients, revealing that online forms provide meaningful and valid data. The Internet group data was mostly equivalent although slightly higher, and no statistically significant results were obtained. The authors suggest that the differences may be due to less inhibition given the anonymity of an online form.

\section{AUDIOLOGICAL INTERVENTION}

A sequence of four reports on Internet-based cognitive behavioral self-help treatment for tinnitus was presented by the same research group in Sweden. ${ }^{33-36}$ The treatment program was a self-help manual constructed following cognitive behavioral principles and included 10 components presented in six modules on a weekly basis for 6 weeks. This self-help program was presented on Web pages, and weekly diaries were submitted to follow progress and give feedback. Outcome measures included several questionnaires and ratings of tinnitus-related handicap, reaction, anxiety, depression, and insomnia (e.g., Tinnitus Reaction Questionnaire and Tinnitus Handicap Inventory) conducted before treatment, after treatment, and at 1-year follow-up. The first report compared a randomized controlled trial of Internet-based cognitive behavior therapy to conventional cognitive behavioral therapy in a waiting-list control group for distress associated with tinnitus. ${ }^{33}$ Participants receiving treatment via the Internet improved to a significantly greater extent than the control group, with 29\% demonstrating an improvement of at least 50\% on the Tinnitus Reaction Questionnaire as opposed to $4 \%$ in the control group. However, dropout rate in the treatment group was much higher, almost 51\% compared to almost none in the control group. A single case report subsequently illustrated the process of Internetbased cognitive behavioral therapy. ${ }^{34}$ A follow-up nonrandomized clinical study reported on the efficacy of Internet-based treatment in 
a sample of consecutive tinnitus patients. ${ }^{35}$ Significant reductions in distress associated with tinnitus were evident, and at 3-month follow-up the patients had remained improved. The dropout rate was $30 \%$ and primarily attributed to time constraints.

Based on the feedback and clinical experience obtained from these studies, the authors redeveloped the program to improve retention and treatment outcomes and subsequently published a follow-up controlled trial incorporating these changes. ${ }^{36}$ Main changes included expanding the self-help text; having participants define their own treatment goals and set priorities for free time required for treatment before commencement; encouraging participants to plan homework assignments on the Web site; providing more detailed and personalized instructions and registration sheets for printing; considerably expanding the Internet diaries for reporting homework assignments; allowing participants to choose if, and when, to start with some of the less general treatment tools; and ensuring that the Web site was informative regarding expectations. Both treatment groups (Internet-based vs. group cognitive therapy) yielded significant positive results with no significant differences in main outcome measures. The results were relatively stable at 1-year follow-up. The attrition rate was lower than for previous Internet-based treatments for tinnitus, ${ }^{35}$ and the method was 1.7 times as cost-effective as conventional group treatment.

The only peer-reviewed empirical report on hearing aid fitting and verification was recently published by Ferrari and BernardezBraga. $^{37}$ The authors compared probe microphone measurements conducted remotely to verify hearing aid performance to face-toface measurements in a group of 60 adults. This was facilitated by a telehealth setup that included application sharing software, interactive desktop videoconferencing, and a facilitator at the remote site to place the probe and make necessary adjustments. The remote measures significantly correlated with face-to-face measures at all frequencies and the differences varied by only $0-2.2 \mathrm{~dB}$, which corresponds to clinically accepted between-measure variability on probe microphone verification. Some previous reports have, however, discussed the remote fitting and verification of hearing aids through telehealth, but these were either not published in a peer-reviewed journal or did not describe an empirical study. ${ }^{38,39}$ Wesendahl $^{38}$ described the possibility of initial fitting, fine tuning, and follow-up for programmable hearing aids through telehealth applications using a special GSM handheld device (combination of a mobile phone and a hearing programmer) in real acoustic environments. Subsequently, Ferrari $^{39}$ reported on the successful remote fitting of hearing aids through application sharing software and interactive desktop videoconferencing in a group of adults.
Other rehabilitation components of audiological intervention facilitated by telehealth include counseling and cochlear implant mapping. A qualitative multiple case study described an Internet-based counseling program for new hearing aid users through daily e-mail interchanges for 1 month provided by an audiologist. ${ }^{40}$ The data were acquired from interviews, analyses of e-mail interchanges, and from audiological files. Results indicated that this was a powerful communication medium for observing changes in behavior and perception of new hearing aid users. The immediacy of e-mail enabled timely response to concerns. A randomized study recently compared on-site cochlear implant programming to remote cochlear implant mapping in a group of five adults. ${ }^{41}$ Twelve remote cochlear implant mapping sessions and 12 face-to-face sessions were completed at four intervals. Each interval was separated by 3 months in a randomized order with performance evaluations after each of the initial 3-month intervals (all subjects did not participate in the first level). Authors report that remote programming through application sharing proceeded without incident and that no significant differences were evident between the programs established for each subject on each programming day ( $\mathrm{M}-1, \mathrm{M}-8$, and $\mathrm{M}-16$ values were used for comparison; $\mathrm{M}=$ the most comfortable level; 1,8 , and 16 denote the electrode number). In addition, remote and standard recorded threshold neural response imaging values were very similar (not tested statistically). The performance of subjects on either a standard or a remote program after 3 months also showed no statistically significant difference in freefield threshold values $(0.25,0.5,1,2$, and $4 \mathrm{kHz})$ or in disyllabic open word test scores. Therefore, no significant differences between remote and face-to-face cochlear implant programming were evident.

\section{PATIENT AND CLINICIAN PERCEPTIONS}

Five reports contained some mention of patient perceptions, of which only two exclusively surveyed patient perceptions and attitudes toward audiological practices related to telehealth. ${ }^{35,36,41-43}$ The first surveyed 116 adult patients attending four audiological clinics in Australia regarding their attitudes toward telemedicine and willingness to make use of tele-audiological services. ${ }^{42}$ Although $45 \%$ of respondents had used the Internet for health-related matters, only $25 \%$ had been aware of telemedicine previously. Overall, 32\% were willing to use telemedicine, 10\% would sometimes be willing, 28\% were unsure, and 30\% were not willing. These findings indicate that tele-audiology is still a foreign concept to many patients especially in this sample, where more than $46 \%$ of respondents were 65 years and older. ${ }^{42}$ The limitation of the study was that respondents had not experienced tele-audiology and were therefore only commenting on their perceived notions of a telemedicine consultation. 


\section{TELEHEALTH APPLICATIONS IN AUDIOLOGY}

In another study, 202 adult respondents with hearing loss from the United Kingdom, Germany, and the Netherlands indicated their preference for a self-test screening via a questionnaire, telephone, or the Internet. ${ }^{43}$ The respondents were generally enthusiastic about the prospect of self-screening but generally preferred a questionnaire to the Internet, which was preferred to the telephone. The majority of subjects were older than 65 years and were also less likely to be positive about Internet-based screening for hearing. Interestingly, respondents reported trusting results from a questionnaire-based screening more than those from an objective screening procedure although there was sufficiently high trust in objective procedures to fulfill the intention of a screening test-to seek medical assistance. Responses differed among the three countries, but the vast majority of respondents found the prospect of having their hearing screened from home acceptable. ${ }^{43}$

Other reports were primarily intervention-related with a component concerning patient perceptions included. In a report on remote cochlear implant programming, subjects indicated the same satisfaction on the remote and face-to-face sessions, but one in three remote sessions lasted too long as opposed to face-to-face sessions. ${ }^{41}$ Also, in 2 of the 12 remote sessions subjects reported some discomfort and requested the stimulation to be stopped as opposed to the faceto-face sessions.

In a randomized clinical trial of a self-help, Internet-based treatment program for tinnitus based on cognitive behavioral therapy principles, patients were surveyed before treatment commenced on their beliefs about whether the treatment will help them or not (treatment credibility). ${ }^{35}$ Surprisingly, no differences were found in patient preferences or credibility ratings between traditional (faceto-face) and self-help Internet treatments. In a follow-up clinical trial with some adjustments made to the Internet-based program, the credibility rating for the Internet treatment was significantly lower than for the conventional group-based cognitive behavioral treatment. ${ }^{36}$ This was attributed to the timing of the questionnaire administration, which was collected before randomization when participants had less knowledge about the treatment they were to receive (as opposed to the previous clinical trial). In addition, participants were asked to rate the credibility of both treatments instead of rating only the assigned treatment. Further, the authors propose that the actual importance of these findings may be questionable because treatment credibility and preference did not affect outcome.

\section{Conclusions}

Peer-reviewed empirical studies on tele-audiology are limited in number, but the scope of utilization of this technology spans various areas of audiological service delivery including screening, diagnosis, and intervention. Several screening applications for populations consisting of infants, children, and adults have demonstrated the feasibility and reliability of screening facilitated through telehealth using both synchronous and asynchronous models. The diagnostic procedures reported, including audiometry, video-otoscopy, OAE, and $A B R$, confirm clinically equivalent results for remote, telehealthenabled tests compared to conventional face-to-face versions. Further, the few reported intervention studies using telehealth, such as

\section{Table 3. Research and Development Priorities}

\section{for Tele-Audiology}

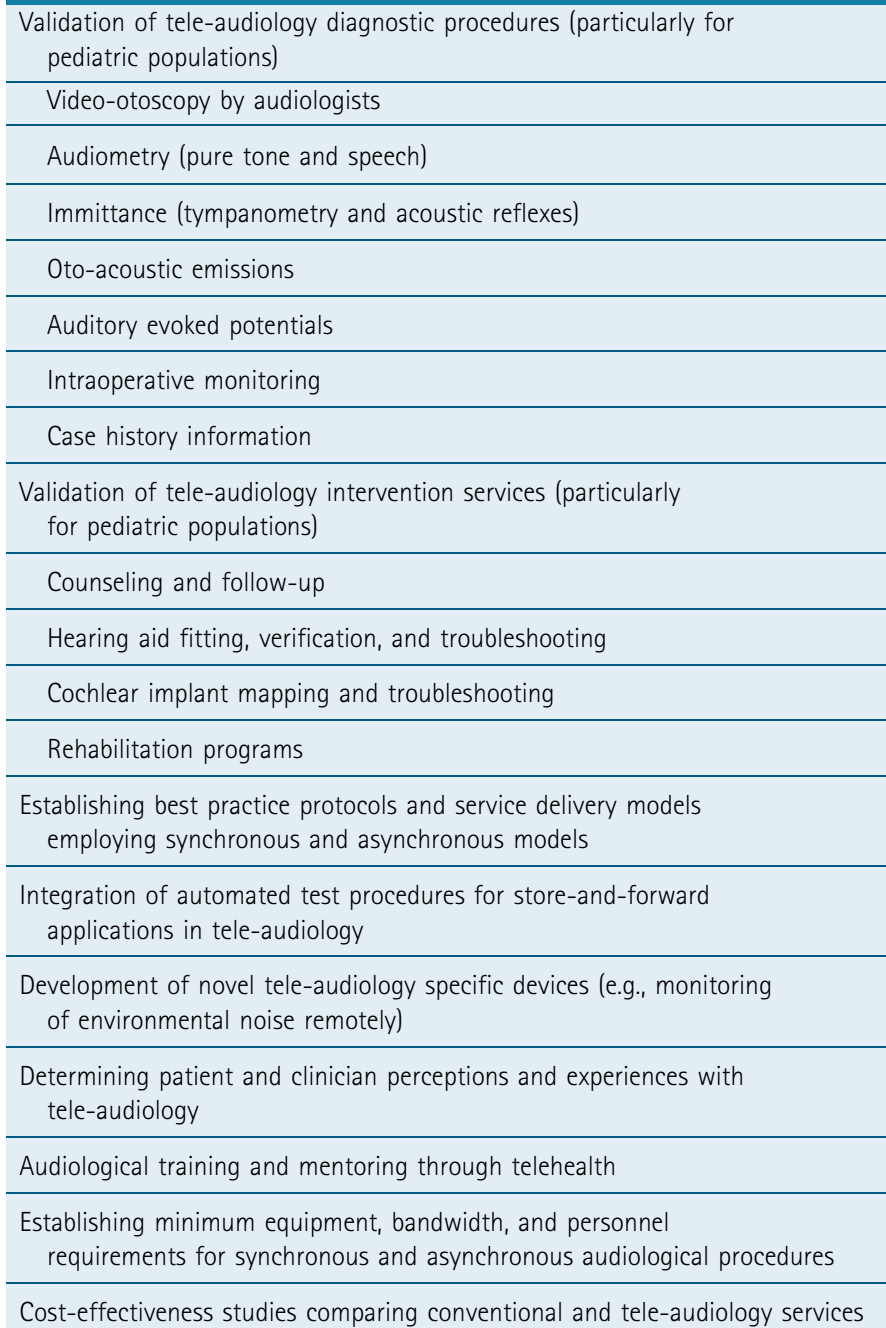

Cost-effectiveness studies comparing conventional and tele-audiology services 
hearing aid verification and Internet-based treatment for tinnitus, demonstrate reliable and effective applications of telehealth compared to conventional face-to-face methods. The very limited information on patient perceptions reveal mixed findings and require more specific investigations, especially post facto surveys of patient experiences. To date, no reports describe audiology clinicians' perceptions of tele-audiology services.

Although initial findings are promising, significant research on audiological practice and education facilitated through telehealth is required as highlighted by the limitations in the depth and breadth of current reports. The majority of these studies on audiological diagnosis and intervention were conducted on adults, and many audiological areas of practice have not been applied through telehealth means. No protocols and service delivery models are currently specified for specific populations, and the current understanding of patient and clinician perceptions is poor and incomplete. Further, important issues such as financial costs and resources for tele-audiology within existing healthcare infrastructures and models remain to be addressed by systematic investigations and cost-analysis studies. Current reports are almost exclusively from research-funded studies and not from existing service delivery mechanisms where healthcare funding models are employed. Although initial evidence suggests that significant cost savings are possible across the scope of audiological services, these must be quantified and potential funding sources/models identified. In developing countries, where medical resources are scarce and telehealth promises cost-efficient access, such studies are particularly important, along with models of funding these services. ${ }^{44}$ Table 3 summarizes the priority areas for future research and development in tele-audiology to address some of these limitations.

As a field in its infancy much work remains to be done to develop and validate tele-audiology as a means of delivering services and for providing training and education. The global absence of hearing healthcare for the vast majority of people with hearing loss raises a moral obligation to pursue ways of penetrating the underserved communities with audiological services. Tele-audiology holds the unique promise of bridging this gap by delivering services through the expanding reach of global connectivity.

\section{Disclosure Statement}

No competing financial interests exist.

\section{REFERENCES}

1. American Academy of Audiology. 2004. Scope of practice. Available at www.audiology.org/resources/documentlibrary/Pages/ScopeofPractice.aspx (last accessed August 5, 2009).
2. American Speech-Language-Hearing Association. 2004. Scope of practice in audiology [scope of practice]. Available at www.asha.org/docs/pdf/SP200400192.pdf (last accessed June 24, 2009).

3. WHO. 2006. Primary ear and hearing care training manuals. Geneva. Available at www.who.int/pbd/deafness/activities/hearing_care/en/index.html (last accessed June 11, 2009).

4. Yoshinaga-Itano C, Sedey A, Coulter D, Mehl A. Language of early- and lateridentified children with hearing loss. Pediatrics 1998;102:1161-1171.

5. Moeller MP, Tomblin JB, Yoshinaga-Itano C, Connor CM, Jerger S. Current state of knowledge: Language and literacy of children with hearing impairment. Ear Hear 2007;28:740-753.

6. Olusanya BO, Ruben RJ, Parving A. Reducing the burden of communication disorders in the developing world: An opportunity for the millennium development project. JAMA 2006;296:441-444.

7. WHO. 2008. The global burden of disease: 2004 update. Geneva. Available at www.who.int/healthinfo/global_burden_disease/GBD_report_2004 update_full.pdf (last accessed May 14, 2009).

8. Yoshinaga-Itano C. Levels of evidence: Universal newborn hearing screening (UNHS) and early hearing detection and intervention systems (EHDI). J Commun Disord 2004;37:451-465.

9. Olusanya BO. Self-reported outcomes of aural rehabilitation in a developing country. Int J Audiol 2004;43:563-571.

10. Goulios H, Patuzzi RB. Audiology education and practice from an international perspective. Int J Audiol 2008;47:647-664.

11. Fagan JJ, Jacobs M. Survey of ENT services in Africa: Need for a comprehensive intervention. Global Health Action 2009;doi:10.3402/gha.v2i0.1932.

12. Wootton $R$. The future use of telehealth in the developing world. In: Wootton $R$, Patil NG, Scott RE, Ho K, eds. Telehealth in the developing world. London: Royal Society of Medicine Press Ltd., 2009:299-308.

13. Swanepoel D, Clark JL, Koekemoer D, Hall III JW, Krumm M, Ferrari DV, McPherson B, Olusanya BO, Mars M, Russo I, Barajas JJ. Telehealth in audiology-The need and potential to reach underserved communities. Int $J$ Audiol (in press).

14. American Academy of Audiology. 2008. The use of telehealth/telemedicine to provide audiology services. Available at www.audiology.org/advocacy/ publicpolicyresolutions/Documents/TelehealthResolution200806.pdf (last accessed May 21, 2009).

15. American Speech-Language-Hearing Association. 2005. Audiologists providing clinical services via telepractice: Technical report [technical report]. Available at www.asha.org/policy (last accessed May 21, 2009).

16. Smits C, Kapteyn T, Houtgast T. Development and validation of an automatic speech-in-noise screening test by telephone. Int J Audiol 2004;43:15-28.

17. Smits C, Merkus P, Houtgast T. How we do it: The Dutch functional hearing screening tests by telephone and Internet. Clin Otolaryngol 2006;31: 436-440.

18. Bexelius C, Honeth L, Ekman A, Eriksson M, Sandin S, Bagger-Sjöbäck D, Litton JE. Evaluation of an Internet-based hearing test-comparison with established methods for detection of hearing loss. J Med Internet Res 2008;10:e32.

19. Krumm M, Huffman T, Dick K, Klich R. Telemedicine for audiology screening of infants. $\underline{J}$ Telemed Telecare 2008;14:102-104 


\section{TELEHEALTH APPLICATIONS IN AUDIOLOGY}

20. Lancaster $P$, Krumm M, Ribera J, Klich R. Remote hearing screenings via telehealth in a rural elementary school. Am J Audiol 2008;17:114-122.

21. Givens GD, Blanarovich A, Murphy T, Simmons S, Blach D, Elangovan S. Internet-based tele-audiometry system for the assessment of hearing: A pilot study. Telemed J E Health 2003;9:375-378.

22. Givens G, Elangovan S. Internet application to tele-audiology-"Nothin' but net." Am J Audiol 2003;12:50-65.

23. Choi J, Lee H, Park C, Oh S, Park K. PC-based tele-audiometry. Telemed J E Health 2007;13:501-508.

24. Krumm M, Ribera J, Klich R. Providing basic hearing tests using remote computing technology. J Telemed Telecare 2007;13:406-410.

25. Ribera J. Interjudge reliability and validation of telehealth applications of the Hearing in Noise Test. Semin Hear 2005;26:13-18.

26. Patricoski C, Kokesh J, Ferguson AS, Koller K, Zwack G, Provost E, Holck P. A comparison of in-person examination and video otoscope imaging for tympanostomy tube follow-up. Telemed J E Health 2003;9:331-344.

27. Kokesh J, Ferguson AS, Patricoski C, Koller K, Zwack G, Provost E, Holck P. Digita images for postsurgical follow-up of tympanostomy tubes in remote Alaska. Otolaryngol Head Neck Surg 2008;139:87-93.

28. Eikelboom RH, Mbao MN, Coates HL, Atlas MD, Gallop MA. Validation of teleotology to diagnose ear disease in children. Int J Pediatr Otorhinolaryngol 2005;69:739-744.

29. Towers AD, Pisa J, Froelich TM, Krumm M. The reliability of click-evoked and frequency-specific auditory brainstem response testing using telehealth technology. Semin Hear 2005;26:19-25.

30. Shapiro WH, Huang T, Shaw T, Roland JT, Lalwani AK. Remote intraoperative monitoring during cochlear implant surgery is feasible and efficient. Otol Neurotol 2008;29:495-498.

31. Virre $E$, Warner $D$, Balch $D$, Nelson JR. Remote medical consultation for vestibular disorders: Technological solutions and case report. Telemed J 1997:3:53-58.

32. Andersson G, Kaldo-Sandström V, Ström L, Strömgren T. Internet administration of the hospital anxiety and depression scale in a sample of tinnitus patients. J Psychosom Res 2003;55:259-262.

33. Andersson G, Strömgren T, Ström L, Lyttkens L. Randomized controlled trial of Internet-based cognitive behavior therapy for distress associated with tinnitus. Psychosom Med 2002;64:810-816.

34. Andersson G, Kaldo V. Internet-based cognitive behavioral therapy for tinnitus. J Clin Psychol 2004;60:171-178.

35. Kaldo-Sandström V, Larsen HC, Andersson G. Internet-based cognitivebehavioral self-help treatment of tinnitus: Clinical effectiveness and predictors of outcome. Am J Audiol 2004;13:185-192.
36. Kaldo V, Levin S, Widarsson J, Buhrman $\mathrm{M}$, Larsen HC, Andersson G. Internet versus group cognitive-behavioral treatment of distress associated with tinnitus: A randomized control trial. Behav Ther $\mathbf{2 0 0 8}$ 39:348-359.

37. Ferrari DV, Bernardez-Braga GR. Remote probe microphone measurement to verify hearing aid performance. J Telemed Telecare 2009;15: 122-124.

38. Wesendahl T. Hearing aid fitting: Application of telemedicine in audiology. Int Tinnitus J 2003;9:56-58.

39. Ferrari DV. Remote programming and verification as a mean to improve quality of hearing aid fitting. In: Rasmussen $A N$, Paulsen $T$, Andersen $T$, Larsen $C B$, eds. Hearing aid fitting. Proceedings of the 21st Danavox Symposium Centertryk, 2006:531-544.

40. Laplante-Lévesque A, Kathleen Pichora-Fuller M, Gagne J-P. Providing an Internet-based audiological counselling programme to new hearing aid users: A qualitative study. Int J Audiol 2006;45:697-706

41. Ramos A, Rodriguez C, Martinez-Beneyto P, Perez D, Gault A, Falcon JC, Boyle P. Use of telemedicine in the remote programming of cochlear implants. Acta Otolaryngol 2009;129:533-540.

42. Eikelboom RH, Atlas MD. Attitude to telemedicine, and willingness to use it, in audiology patients. J Telemed Telecare 2005;11:S22-S25.

43. Koopman J, Davey E, Thomas N, Wittkop T, Verschuure H. How should hearing screening tests be offered? Int J Audiol 2008;47:230-237.

44. Swanepoel DW, Olusanya BO, Mars M. Hearing healthcare delivery in sub-Saharan Africa-Any role for tele-audiology. J Telemed Telecare 2009; doi:jtt.2009.009003.

Address correspondence to:

De Wet Swanepoel, Ph.D.

Department of Communication Pathology

University of Pretoria

C/O Lynnwood \& Roper

Pretoria 0002

South Africa

E-mail: dewet.swanepoel@up.ac.za

Received: August 5, 2009

Revised: September 3, 2009

Accepted: September 3, 2009 


\section{APPENDIX I: Databases and Search Strategy Details}

\begin{tabular}{|c|c|c|c|c|}
\hline DATABASE & SEARCH STRATEGY & IDENTIFIERS & RESULTS & LIMITERS \\
\hline Medline & $\begin{array}{l}\text { MeSH terms related to telehealth and } \\
\text { audiology for the same article }\end{array}$ & $\begin{array}{l}\text { Telehealth MeSH terms: } \\
\text { "telemedicine" OR "computer communication networks" } \\
\text { Audiology MeSH terms: } \\
\text { "Diagnostic Techniques, Otological" OR "audiology" OR } \\
\text { "hearing disorders" OR "sensory aids" OR "rehabilitation } \\
\text { of hearing impaired" }\end{array}$ & 107 & English \\
\hline Medline & $\begin{array}{l}\text { Audiology-related terms occurring in } \\
\text { all fields of telemedicine-related journals } \\
\text { ( } 8 \text { journals) }\end{array}$ & $\begin{array}{l}\text { Telehealth-related journals: } \\
\text { Any journal with the syllable "tele" in the title } \\
\text { Audiology-related terms: } \\
\text { "audiolog" } \\
\text { OR "auditory" OR "vestibular" OR "cochlear" OR "ear" } \\
\text { OR "tympanometry" OR "immittance" OR "otoacoustic" } \\
\text { OR "tinnitus" OR "hyperacusis" }\end{array}$ & 33 & English \\
\hline Medline & $\begin{array}{l}\text { Telehealth-related terms occurring in all } \\
\text { fields of audiology-related journal articles } \\
\text { ( } 45 \text { journals) }\end{array}$ & $\begin{array}{l}\text { Audiology-related journals: } \\
\text { Any journal containing "oto" OR "audiolog"a OR "ear" } \\
\text { OR "hearing" OR "communication disorders" in the title } \\
\text { Telehealth-related terms: } \\
\text { "tele-audiology" OR "telehearing" OR "telehealth" } \\
\text { OR "telemedicine" OR "e-health" OR "telepractice" } \\
\text { OR "Internet" }\end{array}$ & 128 & English \\
\hline SCOPUS & $\begin{array}{l}\text { Telehealth- and audiology-related terms } \\
\text { occurring in the title, abstract, } \\
\text { or keywords of articles }\end{array}$ & $\begin{array}{l}\text { Telehealth-related terms: } \\
\text { "tele-audiology" OR "telehearing" OR "telehealth" } \\
\text { OR "telemedicine" OR "e-health" OR "telepractice" } \\
\text { Audiology-related terms: } \\
\text { "audiolog"a OR "audiometr"a OR "hearing" OR "otoscopy" } \\
\text { OR "auditory" OR "vestibular" OR "cochlear" OR "ear" } \\
\text { OR "tympanometry" OR "immittance" OR "otoacoustic" } \\
\text { OR "tinnitus" OR "hyperacusis" }\end{array}$ & 101 & $\begin{array}{l}\text { English; } \\
\text { exclude re- } \\
\text { views and } \\
\text { editorials }\end{array}$ \\
\hline CINAHL & $\begin{array}{l}\text { Telehealth- and audiology-related terms } \\
\text { occurring in main subject words of } \\
\text { articles }\end{array}$ & $\begin{array}{l}\text { Telehealth-related terms: } \\
\text { "tele-audiology" OR "telehearing" OR "telehealth" } \\
\text { OR "telemedicine" OR "e-health" OR "telepractice" } \\
\text { Audiology-related terms: } \\
\text { "audiolog"a OR "audiometr"a OR "hearing" OR "otoscopy" } \\
\text { OR "auditory" OR "vestibular" OR "cochlear" OR "ear" } \\
\text { OR "tympanometry" OR "immittance" OR "otoacoustic" } \\
\text { OR "tinnitus" OR "hyperacusis" }\end{array}$ & 29 & $\begin{array}{l}\text { English; peer } \\
\text { reviewed; re- } \\
\text { search article }\end{array}$ \\
\hline
\end{tabular}

any word starting with the specified part of a word, e.g., "audiologic" will include terms such as "audiological" and "audiology." 


\begin{tabular}{|c|c|c|c|c|c|c|c|c|}
\hline AUTHORS & YEAR & JOURNAL & CATEGORY & STUDY TYPE & $\begin{array}{l}\text { MODEL/ } \\
\text { CONNECTION/ } \\
\text { DISTANCE }\end{array}$ & SUBJECTS & PROCEDURES & CONCLUSIONS \\
\hline Virre et al. ${ }^{31}$ & 1997 & $\begin{array}{l}\text { Telemedicine } \\
\text { Journal }\end{array}$ & Diagnostic & $\begin{array}{l}\text { Proof-of- } \\
\text { concept study. } \\
\text { Case report on } \\
\text { remote bal- } \\
\text { ance disorder } \\
\text { consultation }\end{array}$ & $\begin{array}{l}\text { Asynchronous; } \\
\text { T1 connection } \\
\text { and distance } \\
\text { unspecified }\end{array}$ & $\begin{array}{l}\text { Single-case } \\
\text { adult report }\end{array}$ & $\begin{array}{l}\text { Cameras allow- } \\
\text { ing patient } \\
\text { eye move- } \\
\text { ments to be } \\
\text { recorded }\end{array}$ & $\begin{array}{l}\text { Effective con- } \\
\text { sultation of } \\
\text { balance disor- } \\
\text { ders and } \\
\text { analysis of } \\
\text { nystagmus } \\
\text { remotely }\end{array}$ \\
\hline 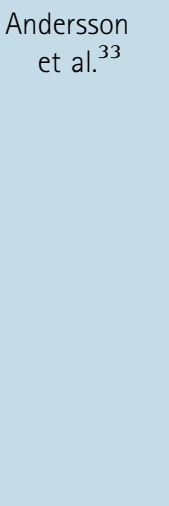 & 2002 & $\begin{array}{l}\text { Psychosomatic } \\
\text { Medicine }\end{array}$ & Intervention & $\begin{array}{l}\text { Randomized } \\
\text { controlled } \\
\text { trial of In- } \\
\text { ternet-based } \\
\text { cognitive } \\
\text { behavioral } \\
\text { therapy for } \\
\text { tinnitus-re- } \\
\text { lated distress }\end{array}$ & $\begin{array}{l}\text { Asynchronous } \\
\text { self-help; } \\
\text { Internet- } \\
\text { based }\end{array}$ & $\begin{array}{l}\text { Adult subjects } \\
\text { with history } \\
\text { of at least } 6 \\
\text { months of } \\
\text { tinnitus. } 117 \\
\text { adults on } \\
\text { the Internet- } \\
\text { based treat- } \\
\text { ment }\end{array}$ & $\begin{array}{l}117 \text { adult sub- } \\
\text { jects as- } \\
\text { signed to the } \\
\text { two groups }\end{array}$ & $\begin{array}{l}\text { High dropout } \\
\text { rate for In- } \\
\text { ternet-based } \\
\text { treatment. } \\
\text { But results } \\
\text { indicate In- } \\
\text { ternet-based } \\
\text { treatment } \\
\text { can } \\
\text { decrease the } \\
\text { annoyance } \\
\text { associated } \\
\text { with tinnitus }\end{array}$ \\
\hline $\begin{array}{c}\text { Andersson } \\
\text { et al. }\end{array}$ & 2003 & $\begin{array}{l}\text { Journal of Psy- } \\
\text { chosomatic } \\
\text { Research }\end{array}$ & Diagnostic & $\begin{array}{l}\text { Proof-of-con- } \\
\text { cept study. } \\
\text { One group } \\
\text { completing } \\
\text { an anxiety } \\
\text { and depres- } \\
\text { sion scale for } \\
\text { tinnitus on } \\
\text { the Internet } \\
\text { and a second } \\
\text { group com- } \\
\text { pleting on } \\
\text { paper with } \\
\text { pen }\end{array}$ & $\begin{array}{l}\text { Asynchronous } \\
\text { Internet- } \\
\text { based }\end{array}$ & $\begin{array}{l}\text { Adults with } \\
\text { tinnitus } \\
\text { completing } \\
\text { question- } \\
\text { naire online } \\
\text { ( } n=157) \text {. } \\
\text { Adults with } \\
\text { tinnitus } \\
\text { completing } \\
\text { question- } \\
\text { naire on pa- } \\
\text { per with } \\
\text { pencil }\end{array}$ & $\begin{array}{l}\text { Questionnaires } \\
\text { completed } \\
\text { online and } \\
\text { with pencil } \\
\text { and paper }\end{array}$ & $\begin{array}{l}\text { The Internet } \\
\text { yielded com- } \\
\text { parable and } \\
\text { valid data }\end{array}$ \\
\hline
\end{tabular}


SWANEPOEL AND HALL

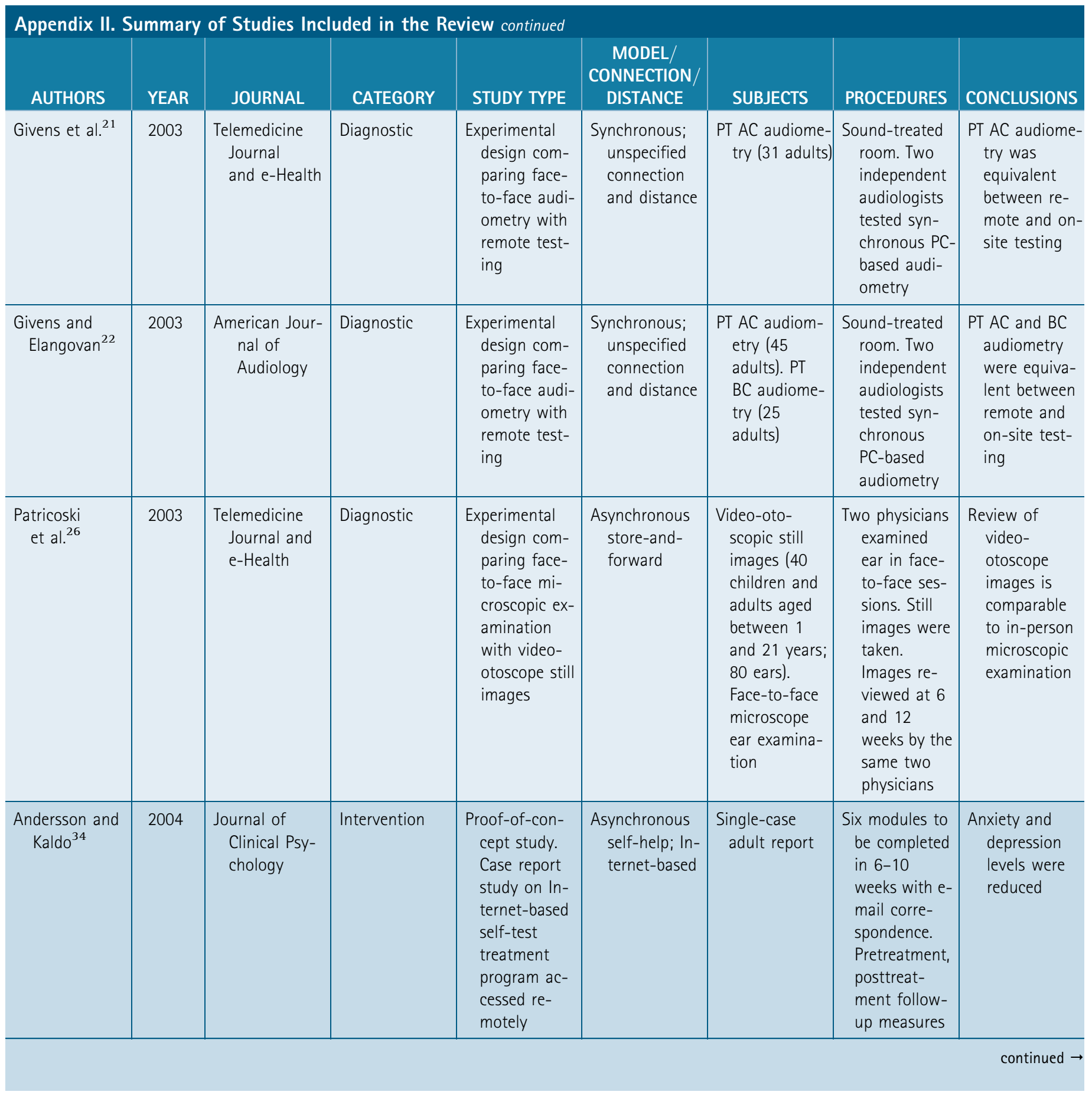




\begin{tabular}{|c|c|c|c|c|c|c|c|c|}
\hline AUTHORS & YEAR & JOURNAL & CATEGORY & STUDY TYPE & $\begin{array}{l}\text { MODEL/ } \\
\text { CONNECTION/ } \\
\text { DISTANCE }\end{array}$ & SUBJECTS & PROCEDURES & CONCLUSIONS \\
\hline $\begin{array}{l}\text { Kaldo- } \\
\text { Sandström } \\
\text { et al. }^{35}\end{array}$ & 2004 & $\begin{array}{c}\text { American Jour- } \\
\text { nal of } \\
\text { Audiology }\end{array}$ & $\begin{array}{l}\text { Intervention, } \\
\text { patient per- } \\
\text { ceptions }\end{array}$ & $\begin{array}{l}\text { Nonrandomized } \\
\text { clinical effec- } \\
\text { tiveness } \\
\text { study }\end{array}$ & $\begin{array}{l}\text { Asynchronous } \\
\text { self-help; In- } \\
\text { ternet-based }\end{array}$ & $\begin{array}{l}\text { Internet-based } \\
\text { self-test } \\
\text { treatment } \\
\text { program ac- } \\
\text { cessed re- } \\
\text { motely by } \\
\text { patients (77 } \\
\text { adults) }\end{array}$ & $\begin{array}{l}\text { Six modules to } \\
\text { be completed } \\
\text { in } 6-10 \text { weeks. } \\
\text { Pretreatment, } \\
\text { posttreatment, } \\
\text { and } 3 \text { month } \\
\text { follow-up } \\
\text { measures }\end{array}$ & $\begin{array}{l}\text { Valid procedure } \\
\text { indicating } \\
\text { positive find- } \\
\text { ings but } \\
\text { dropout rates } \\
\text { are problem- } \\
\text { atic }\end{array}$ \\
\hline Smits et al. ${ }^{16}$ & 2004 & $\begin{array}{c}\text { International } \\
\text { Journal of } \\
\text { Audiology }\end{array}$ & Screening & $\begin{array}{l}\text { Proof-of-con- } \\
\text { cept study. } \\
\text { Development } \\
\text { and compari- } \\
\text { son of } \\
\text { speech-in- } \\
\text { noise screen- } \\
\text { ing test over } \\
\text { telephone } \\
\text { and head- } \\
\text { phones }\end{array}$ & $\begin{array}{l}\text { Asynchronous } \\
\text { self-test; In- } \\
\text { ternet-based }\end{array}$ & $\begin{array}{l}\text { Telephone- } \\
\text { based self- } \\
\text { test ( } n=38 \\
\text { subjects; } 22 \\
\text { normal ears, } \\
54 \text { ears with } \\
\text { hearing loss) }\end{array}$ & $\begin{array}{l}\text { Compared } \\
\text { screening in } \\
\text { laboratory } \\
\text { setup using } \\
\text { headphones } \\
\text { and tele- } \\
\text { phones to } \\
\text { telephone } \\
\text { use from } \\
\text { home; com- } \\
\text { pared results } \\
\text { with diag- } \\
\text { nostic HINT }\end{array}$ & $\begin{array}{l}\text { Reliable } \\
\text { screening } \\
\text { test. Tele- } \\
\text { phone and } \\
\text { headphone } \\
\text { screening } \\
\text { was efficient }\end{array}$ \\
\hline $\begin{array}{c}\text { Eikelboom } \\
\text { et al. }{ }^{28}\end{array}$ & 2005 & $\begin{array}{l}\text { International } \\
\text { Journal of } \\
\text { Pediatric } \\
\text { Otorhinolar- } \\
\text { yngology }\end{array}$ & Diagnostics & $\begin{array}{l}\text { Proof-of-con- } \\
\text { cept study. } \\
\text { Comparing } \\
\text { in-person } \\
\text { otoscopic ex- } \\
\text { amination to } \\
\text { digital im- } \\
\text { ages of the } \\
\text { ear canal and } \\
\text { tympanic } \\
\text { membrane }\end{array}$ & $\begin{array}{l}\text { Asynchronous } \\
\text { store-and- } \\
\text { forward }\end{array}$ & $\begin{array}{l}\text { Video- } \\
\text { otoscopic still } \\
\text { images com- } \\
\text { pared to in- } \\
\text { person oto- } \\
\text { scopic exam- } \\
\text { inations ( } 66 \\
\text { children; } 127 \\
\text { ears) }\end{array}$ & $\begin{array}{l}\text { Same physician } \\
\text { conducted } \\
\text { in-person } \\
\text { assessment } \\
\text { and } 1 \text { month } \\
\text { later evalu- } \\
\text { ated digital } \\
\text { images }\end{array}$ & $\begin{array}{l}\text { Digital images } \\
\text { were of good } \\
\text { quality al- } \\
\text { though } \\
\text { poorer with } \\
\text { younger- } \\
\text { aged children }\end{array}$ \\
\hline
\end{tabular}




\begin{tabular}{|c|c|c|c|c|c|c|c|c|}
\hline AUTHORS & YEAR & JOURNAL & CATEGORY & STUDY TYPE & $\begin{array}{l}\text { MODEL/ } \\
\text { CONNECTION/ } \\
\text { DISTANCE }\end{array}$ & SUBJECTS & PROCEDURES & CONCLUSIONS \\
\hline $\begin{array}{l}\text { Eikelboom and } \\
\text { Atlas }^{42}\end{array}$ & 2005 & $\begin{array}{l}\text { Journal of Tele- } \\
\text { medicine and } \\
\text { Telecare }\end{array}$ & $\begin{array}{l}\text { Patient percep- } \\
\text { tions }\end{array}$ & $\begin{array}{l}\text { Descriptive sur- } \\
\text { vey of patient } \\
\text { attitudes }\end{array}$ & $\mathrm{N} / \mathrm{A}$ & $\begin{array}{l}\text { Survey of pa- } \\
\text { tient atti- } \\
\text { tudes to } \\
\text { telemedicine } \\
\text { and willing- } \\
\text { ness to use it } \\
\text { ( } n=116 \\
\text { adult pa- } \\
\text { tients; } 46 \% \\
\text { older than } 65)\end{array}$ & $\begin{array}{l}\text { Questionnaire } \\
\text { completed by } \\
\text { patients at- } \\
\text { tending four } \\
\text { audiology } \\
\text { clinics }\end{array}$ & $\begin{array}{l}30 \% \text { of patients } \\
\text { were unwill- } \\
\text { ing to receive } \\
\text { audiological } \\
\text { services } \\
\text { through tele- } \\
\text { medicine, } \\
32 \% \text { were } \\
\text { willing, 10\% } \\
\text { would be } \\
\text { willing some- } \\
\text { times, and } \\
28 \% \text { were } \\
\text { unsure }\end{array}$ \\
\hline Ribera $^{25}$ & 2005 & $\begin{array}{c}\text { Seminars in } \\
\text { Hearing }\end{array}$ & Diagnostic & $\begin{array}{l}\text { Experimental } \\
\text { design com- } \\
\text { paring face- } \\
\text { to-face eval- } \\
\text { uation with } \\
\text { HINT and re- } \\
\text { mote testing }\end{array}$ & $\begin{array}{l}\text { Synchronous } \\
\text { high-speed } \\
\text { LAN }\end{array}$ & $\begin{array}{r}\text { HINT (20 } \\
\text { adults) }\end{array}$ & $\begin{array}{l}\text { Two setups. } \\
\text { One at two } \\
\text { separate lo- } \\
\text { cations on } \\
\text { the same } \\
\text { LAN. Second } \\
\text { included a } \\
\text { remote site }\end{array}$ & $\begin{array}{l}\text { HINT can be } \\
\text { administered } \\
\text { remotely } \\
\text { with equiva- } \\
\text { lent results }\end{array}$ \\
\hline Towers et al. ${ }^{29}$ & 2005 & $\begin{array}{c}\text { Seminars in } \\
\text { Hearing }\end{array}$ & Diagnostic & $\begin{array}{l}\text { Experimental } \\
\text { design com- } \\
\text { paring face- } \\
\text { to-face ABR } \\
\text { testing with } \\
\text { remote test- } \\
\text { ing }\end{array}$ & $\begin{array}{c}\text { Synchronous; } \\
\text { T1 connec- } \\
\text { tion; unspec- } \\
\text { ified distance }\end{array}$ & $\begin{array}{l}\text { ABR (500, } \\
3,000 \mathrm{~Hz} \text { to- } \\
\text { neburst and } \\
\text { click stimuli) } \\
\text { (15 adults) }\end{array}$ & $\begin{array}{l}\text { Synchronous } \\
\text { PC-based } \\
\text { testing at } 55 \\
\text { and } 75 \mathrm{~dB} \text {. } \\
\text { Two tests } \\
\text { on-site and a } \\
\text { third test } \\
\text { remotely. } \\
\text { Evaluated } \\
\text { latency }\end{array}$ & $\begin{array}{l}\text { Comparable re- } \\
\text { sults be- } \\
\text { tween sites } \\
\text { with values } \\
\text { within clini- } \\
\text { cally } \\
\text { accepted } \\
\text { variability }\end{array}$ \\
\hline
\end{tabular}




\begin{tabular}{|c|c|c|c|c|c|c|c|c|}
\hline AUTHORS & YEAR & JOURNAL & CATEGORY & STUDY TYPE & $\begin{array}{l}\text { MODEL/ } \\
\text { CONNECTION/ } \\
\text { DISTANCE }\end{array}$ & SUBJECTS & PROCEDURES & CONCLUSIONS \\
\hline Smits et al. ${ }^{17}$ & 2006 & $\begin{array}{l}\text { Clinical Otolar- } \\
\text { yngology }\end{array}$ & Screening & $\begin{array}{l}\text { Proof-of-con- } \\
\text { cept study. } \\
\text { Observational } \\
\text { cross-sec- } \\
\text { tional design }\end{array}$ & $\begin{array}{l}\text { Asynchronous } \\
\text { self-test; In- } \\
\text { ternet-based }\end{array}$ & $\begin{array}{l}\text { Speech-in-noise } \\
\text { screening via } \\
\text { telephone } \\
\text { ( } n=6,351 \\
\text { adults and } \\
\text { adolescents) } \\
\text { and via } \\
\text { Internet } \\
\text { ( } n=30,260 \\
\text { adults and } \\
\text { adolescents) }\end{array}$ & $\begin{array}{l}\text { Self-test. Sub- } \\
\text { jects either } \\
\text { call in for the } \\
\text { automated } \\
\text { hearing } \\
\text { screening or } \\
\text { connect to } \\
\text { the Internet } \\
\text { site }\end{array}$ & $\begin{array}{l}\text { Screening is } \\
\text { possible over } \\
\text { the telephone } \\
\text { and Internet. } \\
\text { Calibration is } \\
\text { an issue }\end{array}$ \\
\hline $\begin{array}{l}\text { Laplante- } \\
\text { Lévesque } \\
\text { et al. }^{40}\end{array}$ & 2006 & $\begin{array}{c}\text { International } \\
\text { Journal of } \\
\text { Audiology }\end{array}$ & Intervention & $\begin{array}{l}\text { Qualitative } \\
\text { multiple } \\
\text { case study } \\
\text { design }\end{array}$ & $\begin{array}{l}\text { Asynchronous } \\
\text { Internet- } \\
\text { based }\end{array}$ & $\begin{array}{l}\text { New hearing } \\
\text { aid users ( } 3 \\
\text { adults) }\end{array}$ & $\begin{array}{l}\text { Internet-based } \\
\text { counseling } \\
\text { program } \\
\text { through daily } \\
\text { e-mails for } \\
\text { the first } \\
\text { month from } \\
\text { audiologist. } \\
\text { Data included } \\
\text { interviews } \\
\text { with partici- } \\
\text { pants, e-mail } \\
\text { interchanges, } \\
\text { and audio- } \\
\text { logical files }\end{array}$ & $\begin{array}{l}\text { Powerful com- } \\
\text { munication } \\
\text { medium for } \\
\text { observing } \\
\text { changes in } \\
\text { behavior and } \\
\text { perceptions } \\
\text { of new } \\
\text { hearing aid } \\
\text { users. Imme- } \\
\text { diacy of e- } \\
\text { mail provides } \\
\text { possibility } \\
\text { for timely } \\
\text { response to } \\
\text { concerns }\end{array}$ \\
\hline
\end{tabular}




\begin{tabular}{|c|c|c|c|c|c|c|c|c|}
\hline AUTHORS & YEAR & JOURNAL & CATEGORY & STUDY TYPE & $\begin{array}{l}\text { MODEL/ } \\
\text { CONNECTION/ } \\
\text { DISTANCE }\end{array}$ & SUBJECTS & PROCEDURES & CONCLUSIONS \\
\hline Choi et al. ${ }^{23}$ & 2007 & $\begin{array}{l}\text { Telemedicine } \\
\text { and e-Health }\end{array}$ & Diagnostic & $\begin{array}{l}\text { Experimental } \\
\text { design com- } \\
\text { paring face- } \\
\text { to-face audi- } \\
\text { ometry with } \\
\text { remote test- } \\
\text { ing }\end{array}$ & $\begin{array}{l}\text { Synchronous; } \\
\text { broadband } \\
\text { wired net- } \\
\text { work; } 1 \mathrm{~km} \\
\text { distance }\end{array}$ & $\begin{array}{l}\text { PT AC audiome- } \\
\text { try ( } 12 \text { nor- } \\
\text { mal) }\end{array}$ & $\begin{array}{l}\text { Sound booth. } \\
\text { Synchronous } \\
\text { PC-based au- } \\
\text { diometry }\end{array}$ & $\begin{array}{l}\text { Comparable } \\
\text { thresholds } \\
\text { although } \\
\text { slightly high- } \\
\text { er variation } \\
\text { between re- } \\
\text { mote and } \\
\text { face-to-face } \\
\text { thresholds } \\
\text { compared to } \\
\text { face-to-face } \\
\text { comparison } \\
\text { on PC-based } \\
\text { vs. conven- } \\
\text { tional audi- } \\
\text { ometer }\end{array}$ \\
\hline Krumm et al. ${ }^{24}$ & 2007 & $\begin{array}{l}\text { Journal of Tel- } \\
\text { emedicine } \\
\text { and Telecare }\end{array}$ & Diagnostic & $\begin{array}{l}\text { Experimental } \\
\text { design com- } \\
\text { paring face- } \\
\text { to-face audi- } \\
\text { ometry and } \\
\text { DPOAE eval- } \\
\text { uations with } \\
\text { remote test- } \\
\text { ing }\end{array}$ & $\begin{array}{l}\text { Synchronous; } \\
\text { broadband } \\
\text { LAN; } \\
\text { 1,100 km } \\
\text { distance }\end{array}$ & $\begin{array}{l}\text { PT AC audiom- } \\
\text { etry and } \\
\text { DPOAE ( } 30 \\
\text { adult sub- } \\
\text { jects) }\end{array}$ & $\begin{array}{l}\text { Synchronous } \\
\text { PC-based } \\
\text { audiometry } \\
\text { and DPOAE } \\
\text { in sound } \\
\text { booth }\end{array}$ & $\begin{array}{l}\text { Equivalent re- } \\
\text { sults from } \\
\text { remote loca- } \\
\text { tion }\end{array}$ \\
\hline Bexelius et al. ${ }^{18}$ & 2008 & $\begin{array}{l}\text { Journal of } \\
\text { Medical In- } \\
\text { ternet Re- } \\
\text { search }\end{array}$ & Screening & $\begin{array}{l}\text { Proof-of-con- } \\
\text { cept study } \\
\text { with obser- } \\
\text { vational } \\
\text { cross-sec- } \\
\text { tional design }\end{array}$ & $\begin{array}{l}\text { Asynchronous } \\
\text { self-test; In- } \\
\text { ternet-based }\end{array}$ & $\begin{array}{l}\text { Subjects com- } \\
\text { pleting an } \\
\text { Internet- } \\
\text { based hear- } \\
\text { ing screen- } \\
\text { ing test } \\
(n=88)\end{array}$ & $\begin{array}{l}\text { Description of } \\
\text { results }\end{array}$ & $\begin{array}{l}\text { Hearing } \\
\text { screening } \\
\text { can be con- } \\
\text { ducted over } \\
\text { the Internet. } \\
\text { Calibration is } \\
\text { an issue }\end{array}$ \\
\hline
\end{tabular}




\begin{tabular}{|c|c|c|c|c|c|c|c|c|}
\hline AUTHORS & YEAR & JOURNAL & CATEGORY & STUDY TYPE & $\begin{array}{l}\text { MODEL/ } \\
\text { CONNECTION/ } \\
\text { DISTANCE }\end{array}$ & SUBJECTS & PROCEDURES & CONCLUSIONS \\
\hline Kaldo et al. ${ }^{36}$ & 2008 & $\begin{array}{l}\text { Behavior Ther- } \\
\text { apy }\end{array}$ & $\begin{array}{l}\text { Intervention, } \\
\text { patient per- } \\
\text { ceptions }\end{array}$ & $\begin{array}{l}\text { Randomized } \\
\text { controlled } \\
\text { trial for cog- } \\
\text { nitive behav- } \\
\text { ior therapy } \\
\text { for tinnitus } \\
\text { delivered as } \\
\text { Internet- } \\
\text { based and } \\
\text { standard } \\
\text { group-based }\end{array}$ & $\begin{array}{l}\text { Asynchronous } \\
\text { self-help; In- } \\
\text { ternet-based }\end{array}$ & $\begin{array}{l}\text { Standard group- } \\
\text { based therapy } \\
(n=25 \\
\text { adults). Inter- } \\
\text { net-based } \\
\text { therapy ( } n \\
26 \text { adults) }\end{array}$ & $\begin{array}{l}\text { Comparison of } \\
\text { Internet- } \\
\text { based and } \\
\text { standard } \\
\text { group-based } \\
\text { cognitive } \\
\text { therapy for } \\
\text { tinnitus. Self- } \\
\text { report inven- } \\
\text { tories mea- } \\
\text { suring tinni- } \\
\text { tus distress } \\
\text { immediately } \\
\text { after treat- } \\
\text { ment and } 1 \\
\text { year later }\end{array}$ & $\begin{array}{l}\text { Internet treat- } \\
\text { ment was } \\
\text { comparable, } \\
\text { statistically } \\
\text { and clinically, } \\
\text { to conven- } \\
\text { tional therapy }\end{array}$ \\
\hline $\begin{array}{l}\text { Koopman } \\
\text { et al. }^{43}\end{array}$ & 2008 & $\begin{array}{c}\text { International } \\
\text { Journal of } \\
\text { Audiology }\end{array}$ & $\begin{array}{l}\text { Patient percep- } \\
\text { tions }\end{array}$ & $\begin{array}{l}\text { Survey of pref- } \\
\text { erences for } \\
\text { hearing } \\
\text { screening } \\
\text { delivery } \\
\text { methods }\end{array}$ & $\mathrm{N} / \mathrm{A}$ & $\begin{array}{l}\text { Survey of pref- } \\
\text { erence for } \\
\text { hearing } \\
\text { screening via } \\
\text { question- } \\
\text { naire, tele- } \\
\text { phone, or } \\
\text { Internet } \\
\text { ( } n=202 \text { re- } \\
\text { spondents; } \\
\text { majority over } \\
65 \text { years) }\end{array}$ & $\begin{array}{l}\text { Questionnaires } \\
\text { mailed }\end{array}$ & $\begin{array}{l}\text { Enthusiastic } \\
\text { about pros- } \\
\text { pect of self- } \\
\text { screening. } \\
\text { Question- } \\
\text { naire gener- } \\
\text { ally preferred } \\
\text { to Internet, } \\
\text { which was } \\
\text { preferred to } \\
\text { telephone }\end{array}$ \\
\hline Krumm et al. ${ }^{19}$ & 2008 & $\begin{array}{l}\text { Journal of Tel- } \\
\text { emedicine } \\
\text { and Telecare }\end{array}$ & Screening & $\begin{array}{l}\text { Experimental } \\
\text { design com- } \\
\text { paring face- } \\
\text { to-face } \\
\text { screening } \\
\text { with remote } \\
\text { testing }\end{array}$ & $\begin{array}{l}\text { Synchronous; } \\
\text { broadband } \\
\text { connection; } \\
200 \mathrm{~km} \text { dis- } \\
\text { tance }\end{array}$ & $\begin{array}{l}\text { DPOAE and } \\
\text { AABR } \\
\text { screening } \\
\text { (30 infants) }\end{array}$ & $\begin{array}{l}\text { Synchronous } \\
\text { DPOAE and } \\
\text { AABR testing }\end{array}$ & $\begin{array}{l}\text { Identical find- } \\
\text { ings for re- } \\
\text { mote and on- } \\
\text { site screen- } \\
\text { ings. DPOAE } \\
\text { amplitudes } \\
\text { equivalent } \\
\text { across fre- } \\
\text { quencies be- } \\
\text { tween sites }\end{array}$ \\
\hline
\end{tabular}




\begin{tabular}{|c|c|c|c|c|c|c|c|c|}
\hline AUTHORS & YEAR & JOURNAL & CATEGORY & STUDY TYPE & $\begin{array}{l}\text { MODEL/ } \\
\text { CONNECTION/ } \\
\text { DISTANCE }\end{array}$ & SUBJECTS & PROCEDURES & CONCLUSIONS \\
\hline Shapiro et al. ${ }^{30}$ & 2008 & $\begin{array}{l}\text { Otology and } \\
\text { Neurotology }\end{array}$ & Diagnostic & $\begin{array}{l}\text { Prospective de- } \\
\text { sign to deter- } \\
\text { mine feasibil- } \\
\text { ity and time } \\
\text { efficiency }\end{array}$ & $\begin{array}{l}\text { Synchronous; } \\
\text { unspecified } \\
\text { connection; } \\
\text { same neigh- } \\
\text { borhood }\end{array}$ & $\begin{array}{l}\text { Cochlear im- } \\
\text { plant and } \\
\text { patient re- } \\
\text { sponse to } \\
\text { electrical } \\
\text { stimulation } \\
\text { (4 devices } \\
\text { tested on- } \\
\text { site and } \\
4 \text { tested } \\
\text { remotely) }\end{array}$ & $\begin{array}{l}\text { Operating the- } \\
\text { ater. On-site } \\
\text { audiological } \\
\text { monitoring } \\
\text { and off-site } \\
\text { synchronous } \\
\text { monitoring } \\
\text { through PC- } \\
\text { based appli- } \\
\text { cation shar- } \\
\text { ing }\end{array}$ & $\begin{array}{l}\text { Remote testing } \\
\text { of the co- } \\
\text { chlear im- } \\
\text { plant device } \\
\text { and patient's } \\
\text { response to } \\
\text { electrical } \\
\text { stimulation is } \\
\text { technically } \\
\text { feasible, } \\
\text { time-saving, } \\
\text { practical, and } \\
\text { cost-efficient }\end{array}$ \\
\hline $\begin{array}{l}\text { Lancaster } \\
\text { et al. }^{20}\end{array}$ & 2008 & $\begin{array}{l}\text { American Jour- } \\
\text { nal of } \\
\text { Audiology }\end{array}$ & Screening & $\begin{array}{l}\text { Experimental } \\
\text { design com- } \\
\text { paring face- } \\
\text { to-face } \\
\text { screening } \\
\text { with remote } \\
\text { testing }\end{array}$ & $\begin{array}{l}\text { Synchronous } \\
\text { and asyn- } \\
\text { chronous; } \\
200 \text { kb Inter- } \\
\text { net connec- } \\
\text { tion; 30-mile } \\
\text { distance }\end{array}$ & $\begin{array}{l}\text { Otoscopy, PT } \\
\text { AC audiome- } \\
\text { try, tympa- } \\
\text { nometry (32 } \\
\text { children) }\end{array}$ & $\begin{array}{l}\text { Synchronous } \\
\text { (otoscopy } \\
\text { and PT AC } \\
\text { audiometry), } \\
\text { asynchro- } \\
\text { nous (tym- } \\
\text { panometry) }\end{array}$ & $\begin{array}{l}\text { No statistically } \\
\text { significant } \\
\text { differences } \\
\text { between } \\
\text { screen re- } \\
\text { sults. Oto- } \\
\text { scopy and } \\
\text { tympanome- } \\
\text { try gave } \\
\text { same results. } \\
\text { Pure tone } \\
\text { screen re- } \\
\text { sults dif- } \\
\text { fered in } 5 \\
\text { cases ( } n \\
32 \text { )-only } 5 \\
\text { of } 193 \text { fre- } \\
\text { quencies } \\
\text { tested }\end{array}$ \\
\hline
\end{tabular}




\begin{tabular}{|c|c|c|c|c|c|c|c|c|}
\hline AUTHORS & YEAR & JOURNAL & CATEGORY & STUDY TYPE & $\begin{array}{l}\text { MODEL/ } \\
\text { CONNECTION/ } \\
\text { DISTANCE }\end{array}$ & SUBJECTS & PROCEDURES & CONCLUSIONS \\
\hline Kokesh et al. ${ }^{27}$ & 2008 & $\begin{array}{l}\text { Otolaryngolo- } \\
\text { gy-Head and } \\
\text { Neck Surgery }\end{array}$ & Diagnostic & $\begin{array}{l}\text { Experimental } \\
\text { design. Diag- } \\
\text { nosis from } \\
\text { video-oto- } \\
\text { scopic still } \\
\text { images of } \\
\text { tympanic } \\
\text { membrane } \\
\text { compared to } \\
\text { face-to-face } \\
\text { microscopic } \\
\text { examination }\end{array}$ & $\begin{array}{l}\text { Asynchronous } \\
\text { store-and- } \\
\text { forward }\end{array}$ & $\begin{array}{l}\text { Children be- } \\
\text { tween } 1 \text { and } \\
16 \text { years of } \\
\text { age ( } n=70 \\
\text { ears) for fol- } \\
\text { low-up care } \\
\text { following } \\
\text { tympanost- } \\
\text { omy tube } \\
\text { placement }\end{array}$ & $\begin{array}{l}\text { Video-otoscopy } \\
\text { still images } \\
\text { compared to } \\
\text { on-site } \\
\text { examination } \\
\text { by two } \\
\text { independent } \\
\text { ENTs }\end{array}$ & $\begin{array}{l}\text { Video-otoscopy } \\
\text { still images } \\
\text { are compara- } \\
\text { ble to in- } \\
\text { person } \\
\text { examination. } \\
\text { Store-and- } \\
\text { forward } \\
\text { acceptable } \\
\text { method }\end{array}$ \\
\hline Ramos et al. ${ }^{41}$ & 2009 & $\begin{array}{c}\text { Acta-Otolaryn- } \\
\text { gologica }\end{array}$ & $\begin{array}{l}\text { Intervention, } \\
\text { patient per- } \\
\text { ceptions }\end{array}$ & $\begin{array}{l}\text { Randomized } \\
\text { study } \\
\text { comparing } \\
\text { on-site } \mathrm{Cl} \\
\text { program- } \\
\text { ming to } \\
\text { remote } \mathrm{Cl} \\
\text { program- } \\
\text { ming }\end{array}$ & $\begin{array}{l}\text { Synchronous; } \\
\text { high-speed } \\
\text { connection; } \\
300 \mathrm{~m}\end{array}$ & $\begin{array}{l}\text { Cochlear im- } \\
\text { plant map- } \\
\text { ping (5 adult } \\
\text { subjects) }\end{array}$ & $\begin{array}{l}12 \text { remote and } \\
12 \text { standard } \mathrm{Cl} \\
\text { mapping ses- } \\
\text { sions (4 pro- } \\
\text { gramming } \\
\text { days sepa- } \\
\text { rated by } 3 \\
\text { months) com- } \\
\text { pared pro- } \\
\text { gram parame- } \\
\text { ters, auditory } \\
\text { progress, per- } \\
\text { ceptions of } \\
\text { sessions, } \\
\text { technical as- } \\
\text { pects, risks, } \\
\text { and difficul- } \\
\text { ties }\end{array}$ & $\begin{array}{l}\text { Remote pro- } \\
\text { gramming } \\
\text { without inci- } \\
\text { dents. No } \\
\text { significant } \\
\text { differences } \\
\text { between } \\
\text { groups. Per- } \\
\text { formance in } \\
\text { groups } 3 \\
\text { months post- } \\
\text { programming } \\
\text { indicated no } \\
\text { difference. } \\
\text { Subjects indi- } \\
\text { cated satis- } \\
\text { faction with } \\
\text { both methods }\end{array}$ \\
\hline
\end{tabular}




\begin{tabular}{|c|c|c|c|c|c|c|c|c|}
\hline AUTHORS & YEAR & JOURNAL & CATEGORY & STUDY TYPE & $\begin{array}{c}\text { MODEL/ } \\
\text { CONNECTION/ } \\
\text { DISTANCE }\end{array}$ & SUBJECTS & PROCEDURES & CONCLUSIONS \\
\hline $\begin{array}{l}\text { Ferrari and Ber- } \\
\text { nardez- } \\
\text { Braga }^{37}\end{array}$ & 2009 & $\begin{array}{l}\text { Journal of Tele- } \\
\text { medicine and } \\
\text { Telecare }\end{array}$ & Intervention & $\begin{array}{l}\text { Experimental } \\
\text { design com- } \\
\text { paring face- } \\
\text { to-face verifi- } \\
\text { cation of } \\
\text { hearing aid } \\
\text { performance } \\
\text { with remote } \\
\text { verification }\end{array}$ & $\begin{array}{l}\text { Synchronous; } \\
384 \text { kb LAN; } \\
\text { distance not } \\
\text { specified }\end{array}$ & $\begin{array}{l}\text { Probe micro- } \\
\text { phone mea- } \\
\text { surements } \\
\text { (REUR, REAR, } \\
\text { and REIG). } 60 \\
\text { adult hearing } \\
\text { aid users (105 } \\
\text { ears) }\end{array}$ & $\begin{array}{l}\text { Synchronous } \\
\text { measure- } \\
\text { ments }\end{array}$ & $\begin{array}{l}\text { Comparable re- } \\
\text { sults between } \\
\text { sites with } \\
\text { values within } \\
\text { clinically ac- } \\
\text { cepted vari- } \\
\text { ability }\end{array}$ \\
\hline
\end{tabular}

\section{$\square$ Diagnostic Intervention Screening Patient perceptions}

$A B R$, auditory brainstem response; $A C$, air conduction; $B C$, bone conduction; $C$, cochlear implant; $D P O A E$, distortion product oto-acoustic emissions; HINT, Hearing-in-Noise-Test; LAN, local area network; N/A, not applicable; PC, personal computer; PT, pure tone.

Note: Light blue rows indicate diagnostic, dark blue rows indicate intervention, white rows indicate screening, and gray rows indicate patient perceptions. 